\title{
Retrospective analysis of antibiotic treatments against piscirickettsiosis in farmed Atlantic salmon Salmo salar in Chile
}

\author{
Derek Price ${ }^{1, *}$, Henrik Stryhn ${ }^{1}$, Javier Sánchez ${ }^{1}$, Rolando Ibarra $^{2}$, Alfredo Tello ${ }^{2}$, \\ Sophie St-Hilaire ${ }^{1}$
}

${ }^{1}$ Atlantic Veterinary College, University of Prince Edward Island, 550 University Avenue, Charlottetown, Prince Edward Island, Canada C1A 4P3

${ }^{2}$ Instituto Tecnológico del Salmón, Intesal-SalmonChile, Av Juan Soler Manfredini 41, OF 1802, Puerto Montt, Chile

\begin{abstract}
Piscirickettsiosis is the most prevalent salt-water infectious disease in farmed salmonids in Chile. Antimicrobials are used to treat this disease; however, there is growing concern about the poor response to therapeutants on some fish farms. The objective of this study was to assess whether factors such as type of antibiotic used, average fish weight, temperature at the beginning of the treatment, and mortality at the time of treatment administration affect the probability of treatment failure against piscirickettsiosis. Pen-level treatment and production information for the first treatment event from 2014 pens on 118 farms was used in a logistic mixed model to assess treatment failure. We defined a failed treatment as when the average mortality 3 wk after the treatment was above $0.1 \%$. Farm and company were included in the model as random effects. We found that the antibiotic product, mortality level before the treatment, and fish weight at the start of the treatment all had a significant effect on treatment outcome. Our results suggest that antibiotic treatment success is higher if the treatment is administered when mortality associated with piscirickettsiosis is relatively low. We discuss the effect of weight on treatment success and its potential relationships with husbandry practices and drug pharmacokinetics.
\end{abstract}

KEY WORDS: Piscirickettsia salmonis - Piscirickettsiosis - Salmonid rickettsial septicemia · Antibiotic treatment effectiveness

\section{INTRODUCTION}

Salmonid rickettsial septicemia (SRS) or piscirickettsiosis is caused by Piscirickettsia salmonis, a Gram-negative facultative intracellular bacterium (Fryer et al. 1990). This pathogen causes chronic infections in salmonid species with mortality rates ranging from 1.2 to $30.5 \%$ (Jakob et al. 2014). During the grow-out period in the sea, SRS is the most prevalent infectious disease in farmed salmonids in Chile (Sernapesca 2013), and is the main cause of mortality due to infectious diseases in all farmed salmonid species (Atlantic salmon, rainbow trout and coho salmon) (Sernapesca 2012a, 2014). In 2014, piscirickettsiosis- related mortality accounted for approximately $75 \%$ of all mortality due to infectious diseases in Atlantic salmon in Chile (Sernapesca 2015a). Typically, fish are diagnosed with this disease approximately 6 mo post salt-water transfer (Rees et al. 2014). Interventions to control losses include vaccinations, early harvest, and antibiotic treatment.

Although antibiotics currently available for commercial use in Chile against piscirickettsiosis have undergone efficacy trials for drug approval and antibiograms from natural outbreaks indicate that most isolates are susceptible to florfenicol $197 \%$ in 2007 and $82 \%$ in 2008) and oxytetracycline (81\% in 2007 and $40 \%$ in 2008) (Mora 2010), producers have 
reported only partial success with antibiotic treatments against piscirickettsiosis in Chile (Branson \& Diaz-Munoz 1991, Cvitanich et al. 1991, Almendras \& Fuentealba 1997).

Henríquez et al. (2016) analyzed the susceptibility of 292 P. salmonis isolates collected from 2010 to 2014 and found that only $1.7 \%$ and $3.1 \%$ of the isolates were resistant to oxytetracycline and florfenicol, respectively. These are the 2 most commonly used antibiotics in Chile for the treatment of this disease (Sernapesca 2015b). These results indicate that resistance only partially explains treatment failure and the reasons for the lack of treatment success under field conditions may be multifactorial. No clinical field trials have been reported for this bacterial disease, so it is difficult to identify the drivers of treatment failure. The lack of clinical trials is, in part, due to the fact that under field conditions it is neither ethical nor economically viable to have untreated control groups on commercial operations, so we are rarely able to assess antibiotic efficacy against a true negative control group. It is also not common practice to treat pens of fish within a farm with different antibiotics for direct comparisons. It is possible, however, to assess the association between treatment outcome and within- and between-farm level factors by using mixed statistical models in observational studies. These statistical methods have been used to assess sea lice treatments (Gustafson \& Ellis 2006, Jones et al. 2012, Arriagada et al. 2014), but they have not been used to evaluate SRS treatments.

Under the regulations of the Servicio Nacional de Pesca y Acuicultura (Sernapesca), the Chilean National Fisheries and Aquaculture Service, all producers using antibiotic treatments for any reason must report when and what pharmaceutical product is used and the laboratory-confirmed clinical diagnosis associated with the treatment (Sernapesca 2003). For SRS, a number of specific diagnostic tests are acceptable, including direct tissue IFAT and PCR (Sernapesca 2012b). Companies that are members of SalmonChile, the Chilean salmon farmer's association, provide the same information on SRS to the Instituto Tecnológico del Salmón (Intesal), the technical branch of SalmonChile, which provides an opportunity to evaluate antibiotic treatment effects for SRS in Chile. Using these data, the objective of this study was to determine whether the success of an antibiotic treatment against piscirickettsiosis was dependent on the antibiotic product used, water temperature, average fish weight, and/or mortality level when the treatment was administered.

\section{MATERIALS AND METHODS}

\section{Data source}

Intesal provided pen-level weekly data from Atlantic salmon (Salmo salar L.) farms that used either oral oxytetracycline or florfenicol antibiotic treatments against SRS, from November 2013 to November 2014. In total, information from 2014 pens on 118 farms, belonging to 14 companies, in 2 regions of Chile (Los Lagos and Aysén), was extracted from this database. The number of active Atlantic salmon farms in Chile during this time period was between 200 and 250 (Sernapesca 2015a).

Farms are required to report mortality every week by cause of death, based on external clinical signs, but often cause of mortality is classified as 'undetermined.' Further, SRS requires a post-mortem examination and, as it is sometimes subclinical, its classification varies depending on the farm staff. For these reasons, we chose to use total mortality in our analysis once farms declared SRS outbreaks, as we felt this reflected more accurately the mortality associated with this pathogen during outbreaks.

We averaged the total weekly mortality rates $3 \mathrm{wk}$ prior to and $3 \mathrm{wk}$ after the first antibiotic treatment for SRS; pens that had additional antibiotic treatments (i.e. within $3 \mathrm{wk}$ after the treatment finished) were excluded from the analysis. We recorded the product and the dose of the antibiotic used on the farm during each treatment event. From the same Intesal dataset, we also retrieved the farm and company codes, water temperature, and average fish weight the week before the treatment was initiated, for all pens included in our analysis. We assumed all farms participating in our study had a recent, laboratory-confirmed diagnosis of SRS, as required by Sernapesca when an antibiotic treatment is delivered at a farm (Sernapesca 2003). Our analyses were conducted at the pen level.

\section{Statistical analysis}

To assess the efficacy of antibiotics against piscirickettsiosis in commercial operations in the absence of untreated controls, we first had to define a successful treatment event. We chose to use a post-treatment 3 -wk average mortality rate above $0.1 \%$ as our criterion for a failed treatment. We chose this mortality cut-off because it was consistent with other studies (Jakob et al. 2014, Rees et al. 2014), and our industry partners felt it was within the normal base- 
line level for many of the farmers in Chile at the time of this study. We evaluated the associations between different factors and the probability of treatment failure using a logistic regression model with mixed effects.

We assessed whether the antibiotic used, the level of mortality at the start of the treatment, the temperature of the water at time of treatment, and the fish weight at time of treatment were associated with increased or decreased probability of a treatment failure.

The antibiotics assessed in our study were oxytetracycline and florfenicol. These were included in our model as a categorical variable with 2 levels. Although data on flumequine was also available, the number of observations was not sufficient to assess the effect of this antibiotic and control for confounders such as the farm effect. We log-transformed the 3 -wk average mortality rate before the treatment to meet our model assumptions. The average water temperature $\left({ }^{\circ} \mathrm{C}\right)$ at the start of the treatment and average weight $(\mathrm{kg})$ of the fish in the pen were included in the model as continuous predictors, and were centered by subtracting the mean. Also, quadratic terms were evaluated for all continuous variables. All possible 2-way and 3-way interactions were initially assessed in the model.

We used forward stepwise selection and backward elimination methods with relaxed $p$-values $(p<0.1)$ to select relevant predictors. We retained only interaction terms that had overall $\mathrm{p}$-values $<0.05$.

Overall significance for categorical variables in our model was obtained using Wald tests; this test was also used to test significance of weight and premortality level over each product individually. When the variable had a significant quadratic term we assessed it by jointly testing the linear and the quadratic terms. Likelihood ratio tests were used to evaluate the effect of removing variables involved in interaction terms. The company and the farm were modeled as nested random effects to account for the hierarchical structure of the dataset.

We used our final model to create predictions for the probability of failure for the different products at selected levels of pre-treatment mortality and weights of the fish. We assessed the differences between products using pairwise comparisons under these scenarios.

Our diagnostics for the predicted random effects consisted of checking normality both graphically, using quantile plots, and statistically, by performing Shapiro-Wilk tests. The effects of extreme observations (Pearson residuals above or below 3) were also examined by running the models with and without these data and comparing conclusions. Stata ${ }^{\circledR}$ version 13.1 (StataCorp) was used for all statistical analyses, and version 14 was used to obtain predicted probabilities.

\section{RESULTS}

\section{Descriptive statistics}

The outcome and significant predictors in our final model were summarized using descriptive statistics (Table 1). During the study period, the average water temperature was $11.49^{\circ} \mathrm{C}\left(7.40-15.20^{\circ} \mathrm{C}\right)$. The average fish weight at the start of the treatment was $1.82 \mathrm{~kg}$ $(0.11-5.6 \mathrm{~kg})$, but there was a difference in the average weight when the data were stratified by product (Table 1). The median mortality before the treatment was $0.07 \%(0.01-2.33 \%)$, while the median mortality after the treatment was $0.09 \%(0.01-11.77 \%)$. Using our treatment success cut-off, in total $47.4 \%$ of the treatments failed in our study, but the failure rate varied by product, $48.1 \%$ and $43.8 \%$ for florfenicol and oxytetracycline, respectively.

Table 1. Summary statistics of antibiotic treatment efficacy predictors and outcome by product

\begin{tabular}{|c|c|c|c|}
\hline $\begin{array}{l}\text { Variable } \\
\text { Statistic }\end{array}$ & $\begin{array}{c}\text { Florfenicol } \\
(\mathrm{n}=1694)\end{array}$ & $\begin{array}{c}\text { Oxytetracycline } \\
(\mathrm{n}=320)\end{array}$ & $\begin{array}{c}\text { Total } \\
(\mathrm{n}=2014)\end{array}$ \\
\hline \multicolumn{4}{|l|}{ Water temp. $\left({ }^{\circ} \mathrm{C}\right)$} \\
\hline Mean & 11.57 & 11.07 & 11.49 \\
\hline $\mathrm{SD}$ & 1.22 & 1.18 & 1.23 \\
\hline Min. & 7.40 & 9.00 & 7.40 \\
\hline Max. & 15.20 & 14.20 & 15.20 \\
\hline \multicolumn{4}{|l|}{ Fish weight (kg) } \\
\hline Mean & 2.00 & 0.87 & 1.82 \\
\hline $\mathrm{SD}$ & 1.18 & 0.47 & 1.17 \\
\hline Min. & 0.18 & 0.11 & 0.11 \\
\hline Max. & 5.60 & 2.00 & 5.60 \\
\hline \multicolumn{4}{|c|}{ Fish mortality before treatment (\%) } \\
\hline Min. & 0.01 & 0.01 & 0.01 \\
\hline 25th percentile & 0.04 & 0.05 & 0.04 \\
\hline Median & 0.07 & 0.08 & 0.07 \\
\hline 75th percentile & 0.15 & 0.13 & 0.15 \\
\hline Max. & 2.33 & 2.14 & 2.33 \\
\hline \multicolumn{4}{|c|}{ Fish mortality after treatment (\%) } \\
\hline Min. & 0.01 & 0.01 & 0.01 \\
\hline 25th percentile & 0.05 & 0.06 & 0.05 \\
\hline Median & 0.09 & 0.09 & 0.09 \\
\hline 75th percentile & 0.22 & 0.15 & 0.21 \\
\hline Max. & 11.77 & 1.75 & 11.77 \\
\hline \multicolumn{4}{|c|}{ Treatment failed (\%) } \\
\hline & 48.1 & 43.8 & 47.4 \\
\hline
\end{tabular}




\section{Logistic regression model}

Our final model for the probability that mortality post-treatment is $>0.1 \%$ in pen $i\left(p_{i}\right)$ included the following predictors:

$$
\begin{aligned}
& \operatorname{logit}\left(p_{i}\right)= \\
& \beta_{\text {prod }_{i}}^{0}+\beta_{\text {prod }_{i}}^{1} \ln \left(m_{i}\right)+\beta_{\text {prod }_{i}}^{2} W_{i}+\beta^{3} t_{i}+A_{\text {company }_{i}}+B_{\text {farm }_{i}}
\end{aligned}
$$

where prod is antibiotic product, $m$ is the mortality pre-treatment, $t$ is the temperature when the treatment started, and $w$ is average fish weight.

Overall mortality before treatment, antibiotic product, and fish weight were significantly $(p<0.01)$ associated with the probability of treatment failure, as was the quadratic term for mortality before treatment $(p<0.01)$; however, the effect of temperature was not significant in our final model $(p=0.09)$ (Table 2).

Interpretation of the relationship between the predictors in our model and the probability of treatment failure was challenging due to several significant interactions between variables. For example, the interaction between product and mortality before the treatment was significant $(\mathrm{p}<0.01)$, but the interaction between product and the quadratic term was not

Table 2. Summary of our final logistic model for the probability of antibiotic treatment failure. Coefficients, significance, and odds ratios (OR) are given for fixed effects; variances and intraclass correlations are given for random

\begin{tabular}{|c|c|c|c|c|c|c|}
\hline Term & & Coefficient & SE & $\mathrm{p}$ & OR & $(95 \% \mathrm{CI})$ \\
\hline Intercept & & -0.06 & 0.36 & & & \\
\hline Log pre-treatment & mortality & 1.44 & 0.14 & $<0.01^{\mathrm{a}}$ & 4.20 & $(3.19-5.53)$ \\
\hline (Log pre-treatmen & $\mathrm{t}$ mortality) $^{2}$ & )$^{2}-0.41$ & 0.08 & $<0.01^{\mathrm{b}}$ & 0.67 & $(0.57-0.78)$ \\
\hline Fish weight & & 0.67 & 0.14 & $<0.01^{\mathrm{a}}$ & 1.95 & $(1.47-2.58)$ \\
\hline Water temperature & & 0.23 & 0.13 & $0.09^{b}$ & 1.25 & $(0.97-1.63)$ \\
\hline $\begin{array}{l}\text { Product } \\
\text { Oxytetracycline }\end{array}$ & & -2.01 & 1.07 & $<0.01^{\mathrm{b}}$ & 0.13 & $(0.02-1.10)$ \\
\hline $\begin{array}{l}\text { Product } \times \text { log pre- } \\
\text { Oxytetracycline }\end{array}$ & treatment m & $\begin{array}{c}\text { mortality } \\
1.07\end{array}$ & 0.38 & $<0.01^{\mathrm{a}}$ & 2.91 & $(1.39-6.11)$ \\
\hline $\begin{array}{l}\text { Product } \times \text { Weight } \\
\text { Oxytetracycline }\end{array}$ & & -2.01 & 0.84 & $0.02^{\mathrm{a}}$ & 0.13 & $(0.03-0.70)$ \\
\hline Random effect & Variance & $\mathrm{SE}$ & $\mathrm{ICC}$ & \multicolumn{2}{|c|}{$(95 \% \mathrm{CI})$} & \\
\hline $\begin{array}{l}\text { Company } \\
\text { Farm }\end{array}$ & $\begin{array}{l}0.87 \\
3.74\end{array}$ & $\begin{array}{l}0.54 \\
0.83\end{array}$ & $\begin{array}{l}0.11 \\
0.58\end{array}$ & \multicolumn{2}{|c|}{$\begin{array}{l}(0.04-0.29) \\
(0.48-0.68)\end{array}$} & \\
\hline \multicolumn{7}{|c|}{$\begin{array}{l}\text { a Obtained using a likelihood ratio test for a reduced model without the } \\
\text { term in question and all its interactions } \\
{ }^{b} \text { Obtained using a Wald test }\end{array}$} \\
\hline
\end{tabular}
effects. $95 \%$ CI: $95 \%$ confidence interval

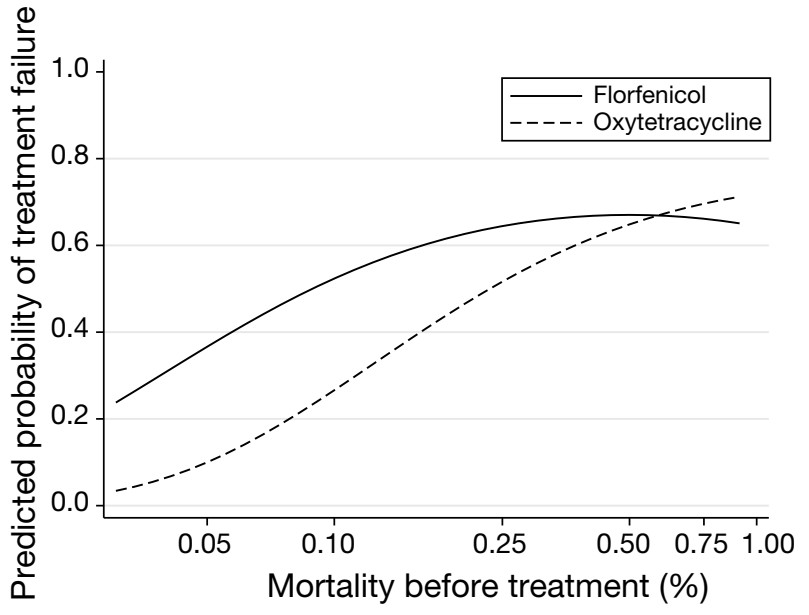

Fig. 1. Predicted probability of salmon Salmo salar mortality $>0.1 \%$ after antibiotic treatment, by level of mortality before the treatment for different products at observed average fish weight and water temperature

$(\mathrm{p}=0.61)$, so it was excluded from the model. In general, the higher the pre-treatment mortality, the higher the probability of having $>0.1 \%$ weekly mortality after the treatment (treatment failure); this relationship was different for each antibiotic product, although they shared a similar curvature (Fig. 1).

More specifically, we found that the pre-treatment mortality rate was significantly associated with treatment outcome for both florfenicol ( $\mathrm{p}<0.01)$ and oxytetracycline $(\mathrm{p}<0.01)$.

The interaction between product and fish weight was also significant ( $p<0.01$ ), but when we examined each product, this relationship was only statistically significant for florfenicol $(\mathrm{p}<0.01)$. Weight was not significantly associated with treatment failure for oxytetracycline $(p=0.11)$.

The effects of company and farm were modeled as random effects, and the intraclass correlations (ICC) for each were 0.11 and 0.58 , respectively, suggesting that pens within the same farm were very similar in their response to treatment (Table 2).

We predicted, using our final model, that when florfenicol was applied to $1 \mathrm{~kg}$ fish with weekly mortality rates at $0.1 \%$, the probability of treatment failure was, on average, $44.5 \%$. Likewise, the average probability of treatment failure for the same group of fish treated with oxytetracy- 
Table 3. Predicted probability of antibiotic treatment failure (\%) with $95 \%$ confidence intervals $(95 \% \mathrm{CI}$; calculated using a normal approximation and bounded between 0 and $100 \%$ ) for different products used on fish of different weights and with different levels of pre-treatment mortality. Predictions only provided for scenarios represented in our dataset. ${ }^{*}$ Significant difference between products at a particular combination of mortality before treatment and fish weight $(p<0.05)$

\begin{tabular}{|c|c|c|c|c|c|c|c|c|c|}
\hline \multirow{4}{*}{$\begin{array}{l}\text { Weight } \\
(\mathrm{kg})\end{array}$} & \multirow{4}{*}{$\begin{array}{l}\text { Product } \\
\text { Florfenicol } \\
\text { Oxytetracycline }\end{array}$} & \multicolumn{8}{|c|}{ - Mortality before treatment $(95 \% \mathrm{CI})(\%)$} \\
\hline & & \multicolumn{2}{|c|}{0.05} & \multicolumn{2}{|c|}{0.1} & \multicolumn{2}{|c|}{0.25} & \multicolumn{2}{|c|}{0.5} \\
\hline & & 25.5 & $(16.0-35.0)$ & 39.7 & $(28.4-51.0)$ & $52.0^{*}$ & $(39.9-64.1)$ & $54.9^{*}$ & $(42.1-67.6)$ \\
\hline & & 25.8 & $(10.9-40.7)$ & 50.7 & $(32.7-68.7)$ & 75.2 & $(58.2-92.3)$ & 84.5 & $(68.9-100.0)$ \\
\hline \multirow[t]{2}{*}{1} & Florfenicol & 29.5 & $(20.1-38.9)$ & 44.5 & $(33.7-55.2)$ & 56.8 & $(45.6-68.1)$ & 59.6 & $(47.7-71.5)$ \\
\hline & Oxytetracycline & 18.6 & $(6.1-31.2)$ & 41.0 & $(23.1-59.0)$ & 67.0 & $(47.0-87.0)$ & 78.1 & $(58.3-98.0)$ \\
\hline \multirow[t]{2}{*}{1.5} & Florfenicol & 33.8 & $(24.3-43.3)$ & 49.3 & $(38.9-59.7)$ & 61.5 & $(51.0-72.1)$ & 64.2 & $(53.1-75.4)$ \\
\hline & Oxytetracycline & $12.9^{*}$ & $(0.0-26.1)$ & 31.9 & $(9.5-54.3)$ & 57.8 & $(30.2-85.4)$ & 70.4 & $(42.7-98.1)$ \\
\hline \multirow[t]{2}{*}{2} & Florfenicol & 38.3 & $(28.6-48.0)$ & 54.1 & $(43.8-64.4)$ & 66.1 & $(55.9-76.2)$ & 68.6 & $(58.0-79.2)$ \\
\hline & Oxytetracycline & $8.6^{*}$ & $(0.0-21.8)$ & $23.8^{*}$ & $(0.0-50.5)$ & 48.1 & $(11.1-85.1)$ & 61.5 & $(23.1-100.0)$ \\
\hline
\end{tabular}

cline was predicted to be $41.0 \%$ (Table 3). In general, our model predicted higher failure rates with increasing pre-treatment mortality rates, and higher failure rates for florfenicol treatments with increasing fish weight (Table 3).

\section{DISCUSSION}

We assessed the effects of selected predictors on SRS mortality and found that results varied, depending on the product used (oxytetracycline or florfeni$\mathrm{col}$ ), the level of mortality, and the fish weight at the start of the treatment. Overall, the higher the weekly mortality rate before the antibiotic treatment was applied, the more likely the post-treatment mortality was above our failure threshold (i.e. $0.1 \%$ ) (Fig. 1). In fact, predictions from our model suggest that when $1 \mathrm{~kg}$ fish with mortality of $0.5 \%$ are treated with either florfenicol or oxytetracycline the probability of failures are $59.6 \%$ and $78.1 \%$, respectively (Table 3). If the same size fish were treated when the mortality level was only $0.05 \%$, then the probability of treatment failure was predicted to be much lower for both products (Table 3).

The relationship between pre-treatment mortality levels and probability of treatment failure may be related to the stage of the disease in the population. Based on infectious disease mortality curves reported for SRS (Jakob et al. 2014), we assumed that pens affected by this disease, which had a higher mortality, also had more fish infected with the pathogen, and that the pathogen load within the tissues of individual fish was higher. One reason for treatment failure may be because fish infected with $P$. salmonis and in the later stages of the disease may have reduced appetite and feed intake (Bravo \& Campos
1989, Fryer \& Lannan 1996). This phenomenon has been observed with other salmonid bacterial diseases (Pirhonen et al. 2003, Toranzo et al. 2005). As a consequence, clinically diseased fish may not consume medication at appropriate levels, and tissue concentrations of antibiotics may not reach the levels required for therapeutic success (Coyne et al. 2004, 2006). This suggests that as the number of infected fish in a population increases, the number of fish that receive an effective treatment decreases, rendering in-feed antibiotic treatments less useful in later stages of this chronic disease. Anorexic fish with SRS would continue to die throughout the treatment period, thus giving the appearance that the antibiotic treatment had failed. To clarify this, we would have needed information on whether fish that died post treatment were 'on feed' at the time the treatment was applied. The fact that infected fish remain in the population after treatment, as is apparent by the high SRS mortality rates post-treatment, poses another issue for the farmer. These infected fish are likely to re-infect other fish once therapy is discontinued. The duration of the treatment effect for SRS on farms is an issue that should be further researched, as there is anecdotal evidence from producers that they have to re-treat for SRS shortly after the first treatment. However, it is unlikely that re-infection of fish was the reason for the high failure rates in this study, because we selected a post-treatment period of only $3 \mathrm{wk}$ to assess the success of treatments and this time frame is shorter than it would have taken after treatment for mortality from new infections (post treatment) to manifest, based on the pathogen's 10-14 d incubation period (Rozas \& Enríquez 2014).

Another factor that may contribute to increased treatment failure when pre-treatment mortality is higher is that in late, more chronic stages of the dis- 
ease, $P$. salmonis is found in the brain tissue (Skarmeta et al. 2000) and skin, which bio-accumulate lower concentrations of florfenicol and oxytetracycline than the kidney (Namdari et al. 1996, Armstrong et al. 2005). The difficulty for many antibiotics in crossing the blood-brain barrier may in part explain the generally low treatment success in pens with high levels of mortality or advanced stages of the disease. Further, because $P$. salmonis is often found intracellularly (Fryer et al. 1990), inhibitory concentrations of antibiotics must be achieved inside infected cells, which may be even harder to achieve when fish are not eating regularly.

The overall low treatment success observed in this study, once mortality was elevated, may also be explained by the fact that late in the disease process the bacteria are no longer replicating rapidly and antibiotics that rely on an active bacterial growth phase for their mechanism of action may not be as effective (Martinez et al. 2013). Thus, even if the pathogen is sensitive to the antibiotic, the antibiotic may fail to remove $P$. salmonis completely from the population.

Our data suggests florfenicol had a lower failure rate in smaller fish, but only some of the pairwise comparisons were statistically significant. Interestingly, our model predicted a slight decline in the probability of failure for florfenicol as pre-treatment mortality increased beyond $0.5 \%$ (Fig. 1). The predicted probability of failure for oxytetracycline treatments also declined slightly, but this effect was observed at a higher pre-treatment mortality rate (data not shown). As Jakob et al. (2014) suggested, this might reflect the natural mortality pattern of SRS, which would eventually decrease as animals mount an immune response and/or the disease progresses through a population. Although there were differences in the relationships between pre-treatment mortality and treatment failure between products, it was very apparent that for the best results, in all cases, antibiotics needed to be applied early in the disease process.

In order to treat fish early in the SRS disease process, when mortalities are low, early detection of infected fish and rapid treatment response are required. In most cases, it takes at least $5 \mathrm{~d}$ to make and ship medicated feed to a salt-water farm in southern Chile (R. Ibarra, Puerto Montt, pers. comm.), so even with a very effective surveillance program for the disease, delays in treatment are unavoidable. Development of risk assessment tools may help identify populations of fish at high risk of developing SRS, so that the time to first treatment can be reduced.
Another finding of this study was that response to the treatment depended on the fish weight; that is, the larger the fish, the lower the probability of treatment success with antibiotics across all levels of pretreatment mortality, at least for florfenicol treatments. Conversely, the fish weight did not significantly affect the probability of treatment outcome for oxytetracycline. Although this trend was not statistically significant it may reflect a difference in the pharmacokinetics of the 2 drugs. It may also be that no treatments with oxytetracycline were observed in this study for fish $>2 \mathrm{~kg}$, probably because of the long withdrawal period associated with this product (Namdari et al. 1996).

The relationship between weight and treatment success for florfenicol may be explained by husbandry practices and pharmacokinetics of the product. In general, in Chile, pens with larger fish tend to have a larger spread in the weights of the animals, as the industry does not grade for size during the salt-water life cycle. This may increase the hierarchical behaviour of fish and cause more fish in the population to obtain less feed. To reduce competition for food and keep feed conversion rates low, it is possible to deliver higher volumes of feed at one time and reduce the feeding frequency (Talbot et al. 1999). With respect to maintaining therapeutic levels of antibiotics a reduction in frequency to 1 or 2 feeds per day in populations with large fish will have different effects, depending on the half-life of the medication.

In Atlantic salmon, the elimination half-life of florfenicol at $11^{\circ} \mathrm{C}$ is $12 \mathrm{~h}$ (Martinsen \& Horsberg 1995). In comparison, oxytetracycline's elimination half-life is about $50 \mathrm{~h}$ at $8^{\circ} \mathrm{C}$ (Elema et al. 1996). Though the half-lives of these products cannot be directly compared, they suggest that maintaining therapeutic tissue concentrations in fish differs between products, and the product with the shortest half-life (florfenicol) would be the hardest to maintain at therapeutic concentrations under these husbandry conditions (i.e. 1 feeding per day). Products with long half-lives, such as oxytetracycline, would bioaccumulate in tissues. If the metabolism of these drugs is not proportional to the fish weight then larger fish may achieve a higher drug tissue concentration by the end of the treatment. This may explain the lower failure rate in larger fish observed for oxytetracycline.

We anticipated temperature would affect the probability of treatment failure, as the replication rate of this pathogen is directly linked to temperature (Larenas \& Contreras 1997, Birkbeck et al. 2004), and the 
metabolism of antibiotics by fish is also temperaturedependent (Rigos et al. 2002), but temperature in our model was not statistically significant (i.e. $\mathrm{p}=0.09$ ). However, because it was biologically relevant and close to significant, we kept it in our final model. We also evaluated a 3-way interaction between product, weight, and temperature, but this was not significant, possibly because our sample size was too small to evaluate 3-way interactions.

It is possible that antibiotic resistance was the reason for some of the poor responses to antibiotics observed in this study. We observed a significant farm effect, which would be consistent with this phenomenon. Although this may explain the general poor treatment response in the industry and at the farm level, the association between pre-treatment mortality level and treatment success was assessed within farms. In other words, even if there was some level of resistance on farms, our analysis demonstrates that pre-treatment mortality and fish weight can affect treatment results. Future research should evaluate whether the failed antibiotic treatment responses cluster in space, as would be expected with resistant strains of the bacteria that are transmitted between neighboring farms (Rees et al. 2014).

To control confounding on farm-level predictors, we included farm as a random effect. This accounted for the differences in exposure and possible resistance between farms, as well as other unmeasured factors at the farm level, such as stressors, co-infection with other pathogens, and management strategies that may influence treatment response. Further, our pen-level predictors, such as pre-treatment mortality and weight of fish, were nested within farms so they would not have been confounded by farm-level factors.

In addition to our inability to measure several farmlevel predictors that may explain the responses to treatments within the industry, there were several other limitations to the study that deserve mention. We defined what we considered a successful treatment threshold, but it is unlikely, given the mortality curves associated with SRS in this study and reported by others (Jakob et al. 2014), that fish would have naturally achieved this threshold weekly mortality $(<0.1 \%)$ within 3 to $6 \mathrm{wk}$ after diagnosis without intervention. Typically, SRS mortality is relatively high and outbreaks last for several months (Jakob et al. 2014, Rees et al. 2014). We recognize that $0.1 \%$ mortality per week may not be the normal baseline mortality for all producers and that our threshold level would affect the classification of a failed treat- ment. To better understand how strongly our threshold choice would affect the conclusions of our study we ran the model with several different cut-off points. When we increased the threshold, this led to small to medium changes in our coefficients; however, the effects of the predictors remained significant, as did our overall conclusions.

We also excluded pens that were re-treated within $3 \mathrm{wk}$ of the first treatment because it was difficult to determine the effect of the initial treatment, but this selection of treatments likely biased the estimate of treatment failures, as well as the association between factors and treatment outcome, towards the null.

\section{CONCLUSIONS}

Our results indicate that it is difficult to treat mortality associated with SRS diagnosis, and that certain factors, such as stage of the disease in the population and fish weight at the time an antibiotic treatment is administered, influence the probability of treatment failure. Although there were limitations to this study, this was the first to evaluate antibiotic treatments against SRS on commercial fish farms, and it has provided us with several biologically plausible hypotheses with which to explain poor treatment responses. Given our results, it is likely that if producers treat their fish very early in the disease process, they will have better success. Our results also suggest that antibiotic treatment outcomes may be influenced by husbandry practices and drug pharmacokinetics. Future research should focus on monitoring and improving treatment efficacy at the population level, e.g. by evaluating feeding strategies for delivery of medication to fish, as well as different doses and duration of treatments in randomized clinical trials. Also, antibiotic sensitivity surveillance with standardized protocols would be an invaluable tool to understand the role of resistance in treatment failure.

Acknowledgements. This research was undertaken, in part, thanks to funding from the Canada Excellence Research Chair Program. We thank Intesal-SalmonChile for the insightful discussions and providing access to Industry data. The authors thank William Chalmers for editorial assistance in preparation of the manuscript.

\section{LITERATURE CITED}

Almendras FE, Fuentealba IC (1997) Salmonid rickettsial septicemia caused by Piscirickettsia salmonis: a review. Dis Aquat Org 29:137-144 
Armstrong S, Hargrave B, Haya K (2005) Antibiotic use in finfish aquaculture: modes of action, environmental fate, and microbial resistance. In: Hargrave B (ed) Environmental effects of marine finfish aquaculture. Springer, Berlin, p 341-357

Arriagada G, Stryhn H, Campistó J, Rees EE and others (2014) Evaluation of the performance of pyrethroids on different life stages of Caligus rogercresseyi in southern Chile. Aquaculture 426-427:231-237

Birkbeck TH, Rennie S, Hunter D, Laidler LA, Wadsworth S (2004) Infectivity of a Scottish isolate of Piscirickettsia salmonis for Atlantic salmon Salmo salar and immune response of salmon to this agent. Dis Aquat Org 60: 97-103

> Branson EJ, Diaz-Munoz DN (1991) Description of a new disease condition occurring in farmed Coho salmon, Oncorhynchus kisutch (Walbaum), in South America. J Fish Dis 14:147-156

Bravo S, Campos M (1989) Coho salmon syndrome in Chile. Am Fish Soc Newsl 17:3

> Coyne R, Samuelsen OB, Bergh Ø, Andersen K, Pursell L, Dalsgaard I, Smith P (2004) On the validity of setting breakpoint minimum inhibition concentrations at one quarter of the plasma concentration achieved following oral administration of oxytetracycline. Aquaculture 239: 23-35

Coyne R, Smith P, Dalsgaard I, Nilsen H, Kongshaug H, Bergh $\varnothing$, Samuelsen OB (2006) Winter ulcer disease of post-smolt Atlantic salmon: An unsuitable case for treatment? Aquaculture 253:171-178

> Cvitanich JD, Garate O, Smith CE (1991) The isolation of a rickettsia-like organism causing disease and mortality in Chilean salmonids and its confirmation by Koch's postulate. J Fish Dis 14:121-145

Elema M, Hoff K, Kristensen H (1996) Bioavailability of oxytetracycline from medicated feed administered to Atlantic salmon (Salmo salar L) in seawater. Aquaculture 143:7-14

Fryer JL, Lannan CN (1996) Rickettsial infections of fish. Annu Rev Fish Dis 6:3-13

- Fryer JL, Lannan CN, Garcés L (1990) Isolation of a rickettsiales-like organism from diseased coho salmon (Oncorhynchus kisutch) in Chile. Fish Pathol 25:107-114

Gustafson L, Ellis SK (2006) Efficacy of emamectin benzoate against sea lice infestations of Atlantic salmon, Salmo salar L.: Evaluation in the absence of an untreated contemporary control. J Fish Dis 29:621-627

Henríquez P, Kaiser M, Bohle H, Bustos P, Mancilla M (2016) Comprehensive antibiotic susceptibility profiling of Chilean Piscirickettsia salmonis field isolates. J Fish Dis (in press) doi:10.1111/jfd.12427

> Jakob E, Stryhn H, Yu J, Medina MH, Rees EE, Sanchez J, St-Hilaire S (2014) Epidemiology of piscirickettsiosis on selected Atlantic salmon (Salmo salar) and rainbow trout (Oncorhynchus mykiss) salt water aquaculture farms in Chile. Aquaculture 433:288-294

> Jones PG, Hammell KL, Dohoo IR, Revie CW (2012) Effectiveness of emamectin benzoate for treatment of Lepeophtheirus salmonis on farmed Atlantic salmon Salmo salar in the Bay of Fundy, Canada. Dis Aquat Org 102: 53-64

Larenas J, Contreras J (1997) Efecto de la densidad poblacional y temperatura en truchas arco iris (Oncorhynchus mykiss) inoculadas con Piscirickettsia salmonis. Arch Med Vet 29:113-119
Martinez MN, Toutain P, Turnidge J (2013) The pharmacodynamics of antimicrobial agents. In: Giguère $\mathrm{S}$, Prescott JF, Dowling PM (eds) Antimicrobial therapy in veterinary medicine. John Wiley \& Sons, Chichester, p 79-103

Martinsen B, Horsberg TE (1995) Comparative single-dose pharmacokinetics of four quinolones, oxolinic acid, flumequine, sarafloxacin, and enrofloxacin, in Atlantic salmon (Salmo salar) held in seawater at $10^{\circ} \mathrm{C}$. Antimicrob Agents Chemother 39:1059-1064

Mora J (2010) Análisis de antibiogramas de cepas de Piscirickettsia salmonis aisladas de salmones y truchas cultivados en las regiones de Los ríos, Los lagos y Aysén los años 2007 y 2008. B VetSci thesis, Universidad de Concepción, Chillán, Chile

Namdari R, Abedini S, Law F (1996) Tissue distribution and elimination of oxytetracycline in seawater Chinook and coho salmon following medicated-feed treatment. Aquaculture 144:27-38

> Pirhonen J, Schreck CB, Reno PW, Ögüt H (2003) Effect of fasting on feed intake, growth and mortality of Chinook salmon, Oncorhynchus tshawytscha, during an induced Aeromonas salmonicida epizootic. Aquaculture 216: 31-38

> Rees EE, Ibarra R, Medina MH, Sanchez J, Jakob E, Vanderstichel R, St-Hilaire S (2014) Transmission of Piscirickettsia salmonis among salt water salmonid farms in Chile. Aquaculture 428-429:189-194

Rigos G, Alexis M, Andriopoulou A, Nengas I (2002) Pharmacokinetics and tissue distribution of oxytetracycline in sea bass, Dicentrarchus labrax, at two water temperatures. Aquaculture 210:59-67

> Rozas M, Enríquez R (2014) Piscirickettsiosis and Piscirickettsia salmonis in fish: a review. J Fish Dis 37:163-188

Sernapesca (2003) Programa Sanitario de Manejo de Enfermedades (PSGE). Resolución No. 67/2003, Servicio Nacional de Pesca y Acuicultura, Valparaíso. www.sernapesca. $\mathrm{cl} /$ index.php?option=com_remository\&Itemid=246\&func $=$ startdown\&id=7603 (accessed Dec 29, 2015)

Sernapesca (2012a) Informe sanitario de salmonicultura en centros marinos año 2012. Unidad de salud animal, Servicio Nacional de Pesca y Acuicultura, Valparaíso. www. sernapesca.cl/index.php?option=com_remository\&Itemid $=246 \&$ func $=$ startdown\&id=6820 (accessed Jul 22, 2015)

Sernapesca (2012b) Programa Sanitario Específico de Vigilancia y Control de Piscirickettsiosis (PSEVC-Piscirickettsiosis). Resolución Exenta No. 3174/2012, Servicio Nacional de Pesca y Acuicultura, Valparaíso. www. sernapesca.cl/index.php?option=com_remository\&Itemid =246\&func=startdown\&id=6737 (accessed Dec 29, 2015)

Sernapesca (2013) Resultados primer semestre de implementación programa sanitario especifico de vigilancia y control de la piscirickettsiosis. Unidad de Salud Animal, Servicio Nacional de Pesca y Acuicultura, Valparaíso. www.sernapesca.cl/index.php?option=com_remository\& Itemid=246\&func=startdown\&id=7647 $($ accessed Jul 22, 2015)

Sernapesca (2014) Informe sanitario de salmonicultura en centros marinos año 2013. Unidad de Salud Animal, Servicio Nacional de Pesca y Acuicultura, Valparaíso. www. sernapesca.cl/index.php?option=com_remository\&Itemid $=246 \&$ func $=$ startdown\&id=8014 (accessed July 22, 2015)

Sernapesca (2015a) Informe sanitario de salmonicultura en centros marinos año 2014. Departamento de Salud Animal, Servicio Nacional de Pesca y Acuicultura, Valparaíso. 
http://sernapesca.cl/index.php?option=com_remository\& Itemid $=246 \&$ func $=$ startdown\&id=11083 $($ accessed Oct 27, 2015)

Sernapesca (2015b) Informe sobre uso de antimicroianos en la salmonicultura nacional 2014. Departamento de Salud Animal, Servicio Nacional de Pesca y Acuicultura, Valparaíso. https://www.sernapesca.cl/index.php?option=com remository\&Itemid=246\&func=fileinfo\&id=11465 (accessed Jan 14, 2016)

Skarmeta AM, Henriquez V, Zahr M (2000) Isolation of a

Editorial responsibility: Stewart Johnson,

Nanaimo, British Columbia, Canada virulent Piscirickettsia salmonis from the brain of naturally infected coho salmon. Bull Eur Assoc Fish Pathol 20: 261-264

Talbot C, Corneillie S, Korsoen O (1999) Pattern of feed intake in four species of fish under commercial farming conditions: implications for feeding management. Aquacult Res 30:509-518

Toranzo AE, Magariños B, Romalde JL (2005) A review of the main bacterial fish diseases in mariculture systems. Aquaculture 246:37-61

Submitted: August 12, 2015; Accepted: February 8, 2016 Proofs received from author(s): February 26, 2016 